\title{
ON AN ALBUM OF PHOTOGRAPHS RECORDING FOSSILS IN THE "OLD COLLECTIONS" OF THE MUSEO DE LA PLATA AND AMEGHINO'S PRIVATE COLLECTION AT THE BEGINNING OF THE XX'TH CENTURY
}

\author{
SERGIO F. VIZCAÍNO' \\ GERARDO DE IULIIS² \\ PAUL D. BRINKMAN ${ }^{3}$ \\ RICHARD F. KAY ${ }^{4}$ \\ DANIEL L. BRINKMAN ${ }^{5}$
}

\begin{abstract}
1CONICET, División Paleontología Vertebrados, Unidades de investigación Anexo Museo, FCNyM, Calle 60 y 122, 1900 La Plata, Argentina.
2Department of Ecology and Evolutionary Biology, University of Toronto, 25 Harbord Street, Toronto, Ontario M5S 3G5, Canada and Department of Palaeobiology, Royal Ontario Museum, 100 Queen's Park Circle, Toronto, Ontario M5S 2C6, Canada.

${ }^{3}$ North Carolina Museum of Natural Sciences, 11 W. Jones Street, Raleigh, NC 27601, USA.

${ }^{4}$ Department of Evolutionary Anthropology and Division of Earth and Ocean Sciences (Nicholas School of the Environment), Duke University, Box 90383, Durham, NC 27708, USA.

${ }^{5}$ Division of Vertebrate Paleontology, Yale Peabody Museum of Natural History, 170 Whitney Avenue, P.O. Box 208118, New Haven, CT 06520-8118, USA.
\end{abstract}

Recibido: 16 de mayo de 2017 - Aceptado: 21 de junio de 2017

Para citar este artículo: Sergio F. Vizcaíno, Gerardo De luliis, Paul D. Brinkman, Richard F. Kay, and Daniel L. Brinkman (2017). On an album of photographs recording fossils in the "Old collections" of the Museo de la Plata and Ameghino's private collection at the beginning of the $\mathrm{XX}^{\mathrm{TH}}$ century. Publicación Electrónica de la Asociación Paleontológica Argentina 17 (1): 14-23.

Link a este artículo: http://dx.doi.org/10.5710/PEAPA.21.06.2017.244

DESPLAZARSE HACIA ABAJO PARA ACCEDER AL ARTÍ́CULO

Asociación Paleontológica Argentina Maipú $6451^{\circ}$ piso, C1006ACG, Buenos Aires

República Argentina

Tel/Fax (54-11) 4326-7563

Web: www.apaleontologica.org.ar

Otros artículos en Publicación Electrónica de la APA 16(2):

\section{Deschamps \& Tomassini}

LATE CENOZOIC VERTEBRATES FROM THE SOUTHERN PAMPEAN REGION: SYSTEMATIC AND BIO-CHRONOSTRATIGRAPHIC UPDATE

\section{Borromei et al.}

POSTGLACIAL VEGETATION AND CLIMATE CHANGES INFERRED FROM A PEAT POLLEN RECORD IN THE RÍO PIPO VALLEY, SOUTHERN TIERRA DEL FUEGO 


\title{
ON AN ALBUM OF PHOTOGRAPHS RECORDING FOSSILS IN THE "OLD COLLECTIONS" OF THE MUSEO DE LA PLATA AND AMEGHINO'S PRIVATE COLLECTION AT THE BEGINNING OF THE XX'H CENTURY
}

\author{
SERGIO F. VIZCAÍNO ${ }^{1}$, GERARDO DE IULIIS², PAUL D. BRINKMAN³ ${ }^{3}$ RICHARD F. KAY4, AND DANIEL L. BRINKMAN ${ }^{5}$
}

${ }^{1}$ CONICET, División Paleontología Vertebrados, Unidades de investigación Anexo Museo, FCNyM, Calle 60 y 122, 1900 La Plata, Argentina. vizcaino@fcnym.unlp.edu.ar ${ }^{2}$ Department of Ecology and Evolutionary Biology, University of Toronto, 25 Harbord Street, Toronto, Ontario M5S 3G5, Canada and Department of Palaeobiology, Royal Ontario Museum, 100 Queen's Park Circle, Toronto, Ontario M5S 2C6, Canada. gerry.deiuliis@utoronto.ca

${ }^{3}$ North Carolina Museum of Natural Sciences, 11 W. Jones Street, Raleigh, NC 27601, USA. paul.brinkman@naturalsciences.org

${ }^{4}$ Department of Evolutionary Anthropology and Division of Earth and Ocean Sciences (Nicholas School of the Environment), Duke University, Box 90383 , Durham, NC 27708, USA.richard.kay@duke.edu

${ }^{5}$ Division of Vertebrate Paleontology, Yale Peabody Museum of Natural History, 170 Whitney Avenue, P.0. Box 208118, New Haven, CT 06520-8118, USA. daniel.brinkman@yale.edu

\begin{abstract}
An album of photographs in the Kansas University Natural History Museum, found together with the Patagonian fossils collected by Handel T. Martin in 1904, was assumed in a recent publication to have been assembled by Martin. It comprises 193 numbered pages and 580 photographs of prepared fossil vertebrate specimens, some labeled as from the Museo de La Plata and others, without labels, which were assumed as having been in Florentino Ameghino's private fossil collection. However, archival evidence in the Yale Peabody Museum indicates that the album is most likely the original copy of the photographic album assembled by William B. Scott during his visit to Argentina in 1901 to examine fossil specimens from Patagonia in the museums of La Plata and Buenos Aires, and in Ameghino's collection. It represents an important record of the specimens present at these institutions and in possession of Ameghino near the turn of the last century, a period during which those fossils aroused considerable scientific interest and were in very high demand among researchers and academic institutions, but marked as well by severe conflicts between F. Ameghino and the Director of the Museo de La Plata, Francisco P. Moreno. As a consequence the collections were subjected to considerable turmoil and many important specimens can no longer be located. The album provides visual references for these specimens and facilitates systematic and taxonomic research by helping to evaluate which specimens were used to erect numerous taxa and which were analyzed by other researchers who published on such remains.
\end{abstract}

Key words. Handel T. Martin. William B. Scott. Florentino Ameghino. Fossil mammals. Santa Cruz Formation. Museo de La Plata. Museo Argentino de Ciencias Naturales.

Resumen. SOBRE UN ÁLBUM DE FOTOGRAFÍAS DE COMIENZOS DEL SIGLO XX DE LAS "VIEJAS COLECCIONES" DEL MUSEO DE LA PLATA Y EN LA COLECCIÓN PRIVADA DE AMEGHINO. En una publicación reciente se asumió que un álbum de fotografías encontrado en el Kansas University Natural History Museum junto con fósiles patagónicos recogidos por Handel T. Martin en 1904 había sido montado por este. El álbum comprende 193 páginas numeradas y 580 fotografías de especímenes de vertebrados fósiles preparados, algunos etiquetados como del Museo de La Plata y otros, sin etiquetas, que se supuso pertenecían a la colección privada de fósiles de Florentino Ameghino. Sin embargo, evidencia de archivo en el Yale Peabody Museum indica que el álbum sería copia del álbum fotográfico original reunido por William B. Scott durante su visita a la Argentina en 1901 para examinar especímenes fósiles de Patagonia en los museos de La Plata y Buenos Aires y en la colección de Ameghino. El álbum representa un registro importante de los especímenes presentes en estas instituciones y en posesión de Ameghino cerca del final del siglo pasado, período durante el cual estos fósiles despertaron considerable interés científico y fueron muy demandados por investigadores e instituciones académicas, pero que también estuvieron signados por graves conflictos entre F. Ameghino y el Director del Museo de La Plata, Francisco P. Moreno. Como consecuencia, las colecciones fueron sometidas a un ajetreo considerable y muchos especímenes importantes ya no pueden localizarse. El álbum proporciona referencias visuales para estos especímenes y facilita la investigación sistemática y taxonómica ayudando a evaluar qué especímenes se utilizaron para erigir numerosos taxones y cuáles fueron analizados por otros investigadores que publicaron sobre ellos.

Palabras clave. Handel T. Martin. William B. Scott. Florentino Ameghino. Mamíferos fósiles. Formación Santa Cruz. Museo de La Plata. Museo Argentino de Ciencias Naturales. 
When Rosendo Pascual (1925-2012), the most impactful advocate of modern mammalian paleontology of South America, began to frequent, as student and volunteer, the División Paleontología Vertebrados (DVP) of the Museo de La Plata (MLP) in the mid-1950s, the only person working there was the preparator Lorenzo Julio Parodi (1890-1969). Parodi had begun working at the MLP in 1937; he had previously assisted Carlos Ameghino (1865-1936), who served as the Director of Museo Nacional (currently the Museo Argentino de Ciencias Naturales "Bernardino Rivadavia" or MACN) during the final years of his life. When Pascual (pers. comm. to SFV, 2008) began assisting Parodi at the MLP, one task was to unpack and make lists of the fossil specimens that had been recovered mainly from the early Miocene Santa Cruz Formation of Argentine Patagonia during the last part of the nineteenth century. They were part of what Pascual informally referred to as the "Antiguas colecciones" ("Old collections") of the MLP. This group of remains must have included specimens collected by Tonnini de Furia, an Italian free-lance collector from whom Francisco P. Moreno (1852-1919), founder and first Director of the MLP, had purchased Santa Cruz fossils that were part of the founding collections of the MLP (Farro, 2009), and those collected during the early MLP expeditions that were conducted by Carlos Ameghino, Santiago Pozzi, Clemente Onelli, Carlos Burmeister, Federico Berry, Juan Ivovich and Francisco Larumbe (Vizcaíno et al., 2013; Brinkman and Vizcaíno, 2014).

According to Pascual's comments to one of the authors (SFV) and to Marcelo Reguero (pers. comm., 2013), curator of the collections of the DVP of the MLP since 1980, it was in many cases impossible to determine who had collected which of the unpacked specimens, given the sparse information associated with them. Cataloguing of the "Old collections" may have been started between 1890 and 1891 by Alcides Mercerat, a Swiss geologist who replaced Florentino Ameghino (1853-1911) at the MLP in 1889, following the latter's sudden departure from the museum over severe disagreements with Moreno. The specimens that Mercerat began to curate are still clearly recognizable, although many others were apparently and unfortunately left uncurated. Mercerat departed from the MLP in 1892 due to his own differences with Moreno. Between 1895 and 1906 the head of the "Sección de Paleontología" of the MLP was the Swiss
Argentine paleontologist Kaspar Jacob Roth, known in Argentina as Santiago Roth, but he apparently made little if any headway in cataloguing of the Santa Cruz specimens. Further, he was involved in the conflict between Moreno and the Ameghino brothers, and competed with C. Ameghino for fossils in Patagonia, albeit in Cenozoic levels in the Territory of Chubut older than those of Santa Cruz (Bond, 1998).

The most scientifically important of the early expeditions was that carried out by C. Ameghino in 1887 on behalf of the MLP (see below). The initial descriptions of some of these remains, including the erection of 110 new taxa, were published in the same year by his brother F. Ameghino (1887). The publication included neither catalogue numbers nor illustrations of any of the specimens upon which the new taxa were founded (not particularly atypical, given the era during which he worked, although numbering and figuring specimens was becoming more widespread by the late 1800s; e.g., see Schuchert, 1897).

Several problems befell the 1887 collection (Vizcaíno and Bargo, 2013; Vizcaíno et al., 2013); these problems continue to be a source of confusion up to the present. Although the collection should have been housed in the MLP, given that it was made on behalf of that institution, some of the specimens were retained by $\mathrm{F}$. Ameghino for his private collection. Ameghino's private collection, which also included specimens later recovered by C. Ameghino from Santa Cruz, was eventually acquired from the Ameghino family by the Argentine national authorities in the 1930s, following the death of both brothers, and it was deposited in the Museo Nacional (MACN, where it still resides) (Rusconi, 1965; Fernicola, 2011a). Fernicola (2011a) has demonstrated that at least some of C. Ameghino's 1887 Santa Cruz specimens are part of the "Colección Nacional Ameghino" ("Ameghino National Collection"). However, important portions were donated, exchanged, or sold to other institutions by Florentino (Vizcaíno and Bargo, 2013; Vizcaíno et al., 2013), so that specimens from C. Ameghino's 1887 and subsequent expeditions may now reside elsewhere. Meanwhile, the specimens that remained in the MLP must have become mixed with specimens collected by subsequent expeditions to the Río Santa Cruz and other localities by Pozzi, Onelli, Burmeister, and Berry. At the end of the 1950s and during the 1960s and 1970s, the DVP of the MLP donated 
or exchanged specimens from the "Old collections" (Vizcaíno et al., 2013). Thus, it seems probable that a few of the specimens from the 1887 collection may lie, for all intents and purposes unrecognized, in the drawers of other museums or be in the hands of private individuals.

Mercerat (1891), Lydekker (1894) and Scott (e.g., 1903, 1904) were the earliest reviewers of the Ameghinos' work, but only the latter had the opportunity to observe specimens in Ameghino's private collection; some of these specimens are recorded in the Princeton Expedition volumes (see below). Lydekker (1894) and Scott (e.g., 1903, 1904) provided illustrations of several -but not all- of the specimens, drawings in the case of Scott and (a few) photographs in the case of Lydekker. But due to the circumstances noted above, it is not possible to determine with confidence which specimens these researchers observed in the MLP and whether they were the same as those upon which Ameghino based his original descriptions of the Santa Cruz specimens. Further, several of the type specimens cannot be located and are considered lost (see e.g., Kay et al., 2012; De luliis et al., 2014).

Recently Vizcaíno et al. (2016) reported the existence of an album of photographs in the Kansas University Natural History Museum (KUNHM), together with the Santacrucian fossil collection made in 1904 by Handel T. Martin (18621931), that they assumed, in the absence of any archival information in KUNHM on its origin, had been assembled by Martin. The album (see Appendix 1; Supplementary Material) comprised 193 numbered pages (in its current condition, however, six pages are missing; see below) containing a collection of 580 photographs of prepared fossil vertebrate specimens, some labeled as from the Museo de La Plata and others without labels, as well as six photographs of the MLP building and F. Ameghino's house (Fig. 1). The authors assumed that the unlabeled specimens must have been in Ameghino's private fossil collection because at least some of them are now housed at the MACN (see below). Vizcaíno et al. (2016: fig. 3D-G) reproduced four images from the album, two of the MLP and two of the outside of Ameghino's house.

The aim of this contribution is to review the origin of the album and to evaluate its current scientific value in relation to the fossils of the Santa Cruz Formation.

\section{THE REAL ORIGIN OF THE ALBUM}

As part of William B. Scott's (1858-1947) role as editor and contributor to the "Reports of the Princeton University Expeditions to Patagonia, 1896-1899", published as a series of volumes between 1903-1932, Scott visited over several months in 1901 the MLP, the MACN and F. Ameghino's home to study the material in these institutions and Ameghino's private collection. While there, he photographed "the most important specimens, which generally were the types -that is, the specimens on which the published names of genera and species had been first described" (Simpson, 1984, p. 133). Scott (1939, p. 253) stated that "I made up two large albums, one for Ameghino, containing all the pictures I had made of his fossils, and the other, for myself, in which I mounted all the photographs I had taken in La Plata and Buenos Aires." This and Simpson's (1984) remark that Scott presented the first album to F. Ameghino before leaving Argentina implies that the albums were purchased and assembled while Scott was still in Argentina. Thus, Scott left Argentina with one album, assembled from material acquired in Argentina. It is not known whether Scott put together any more albums once he returned to the USA, although he retained the negative photographic glass plates (see below). A search in MLP and MACN, the most likely institutions that would preserve Ameghino's archival material, for the album presented to him by Scott has not been fruitful.

When Princeton University ceased its vertebrate paleontology program during the 1980s, most of Princeton's Santacrucian fossil collection (that had been made largely by John B. Hatcher; 1861-1904) was transferred to the Division of Vertebrate Paleontology of Yale University's Peabody Museum (YPM VP) (see Vizcaíno et al., 2013). This is generally known among vertebrate paleontologists, but it is not well known that other archival material was also transferred, including some of Scott's glass plate negatives, and a notebook that includes the "Index to Album, List of Negatives and Box List of the Photographs of Specimens in the Collections of La Plata \& Buenos Aires" (YPM VP Archive multimedia catalogue number: VPAR.002147; see Appendix 2, Supplementary Material). Indeed, when one of the authors (SVF) requested, during a visit to the Department of Geosciences of Princeton University in 2013, information on Scott's album or images, there seemed to be no record of 

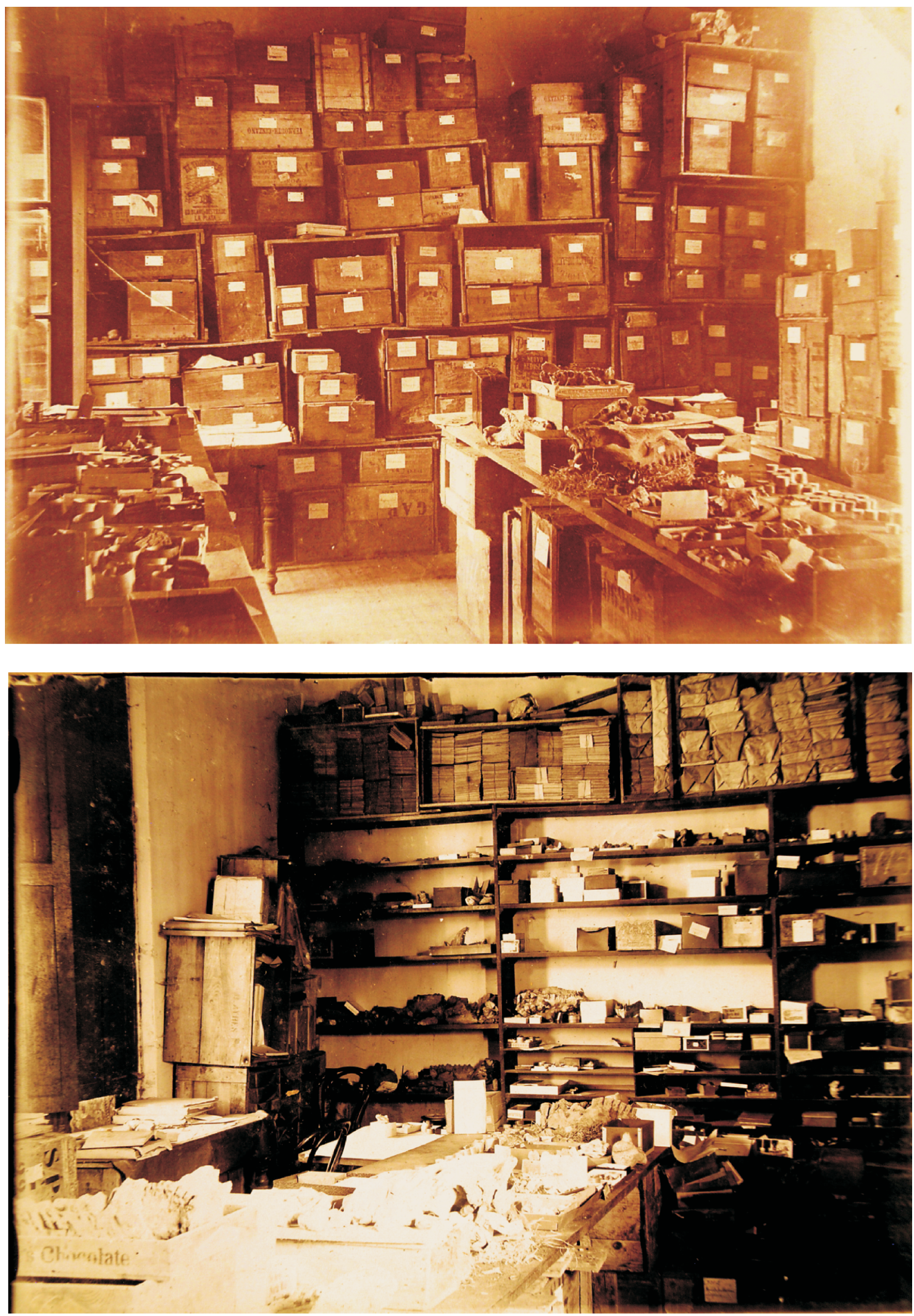

Figure 1. Images from the KUNMH album of Ameghino's fossil collection in his house in La Plata, Argentina. With permission of Leonard Krishtalka and the Biodiversity Institute, Division of Vertebrate Paleontology, University of Kansas. 
their presence. As well, attempts by GDI and PDB to recover this album, independently of SFV, among Scott's archival material in several likely US institutions (e.g., American Museum of Natural History; American Philosophical Society; Firestone Library and Seely G. Mudd Manuscript Library, Princeton University; Manuscripts and Archives, Yale University Library; University of Arizona; University of Florida; YPM VP) were not successful.

Subsequent to the publication of Vizcaíno et al. (2016) and during collaboration between SFV and GDI on the systematic issues of several Santacrucian sloth taxa, with the latter author having just become aware through collaboration with DLB of Scott's glass negatives, notebook, and several modern contact prints made from the negatives, SFV and GDI quickly realized that the KUNHM album could in fact be Scott's album (or a copy of it, though this is unlikely, as suggested below) through the similarity of the few modern prints available of Scott's negatives and the notebook (Fig. 2). Scott's notebook suggests that his photographic album contained 193 pages including 580 photographs, some of single specimens and others of multiple specimens. Unfortunately, the album does not appear to be preserved in the YPM VP. Many of the glass negatives appear to be lost or destroyed: only 241 negatives are conserved in YPM VP, yet Scott's notebook (see Appendix 2 -Supplementary Material- beginning on page 67) lists 580 negatives. Modern contact prints were made (the glass plate negatives were inventoried in 1999, but it is not clear when the prints were made from them) of approximately $40 \%$ of the original glass negatives. Simpson (1932: figs. 6 , 8; 1948: pl. 18, fig. 12) published three of Scott's images.

The images in the KUNHM album match exactly Scott's available modern prints (an example is provided in Figure 2 for comparison) and the number and arrangement of the specimens, as listed in the Index, match exactly those in KUNHM album. It is thus beyond a reasonable doubt that the album in KUNHM is Scott's album. In addition to the matching of specimens and images, the album itself is certainly from Argentina (or at least, the cover is printed in Spanish), suggesting that the album was assembled in Argentina and not the USA (as noted above, Scott indicated that he made two albums with different sets of images, one for Ameghino and the other for himself). Further, the inside
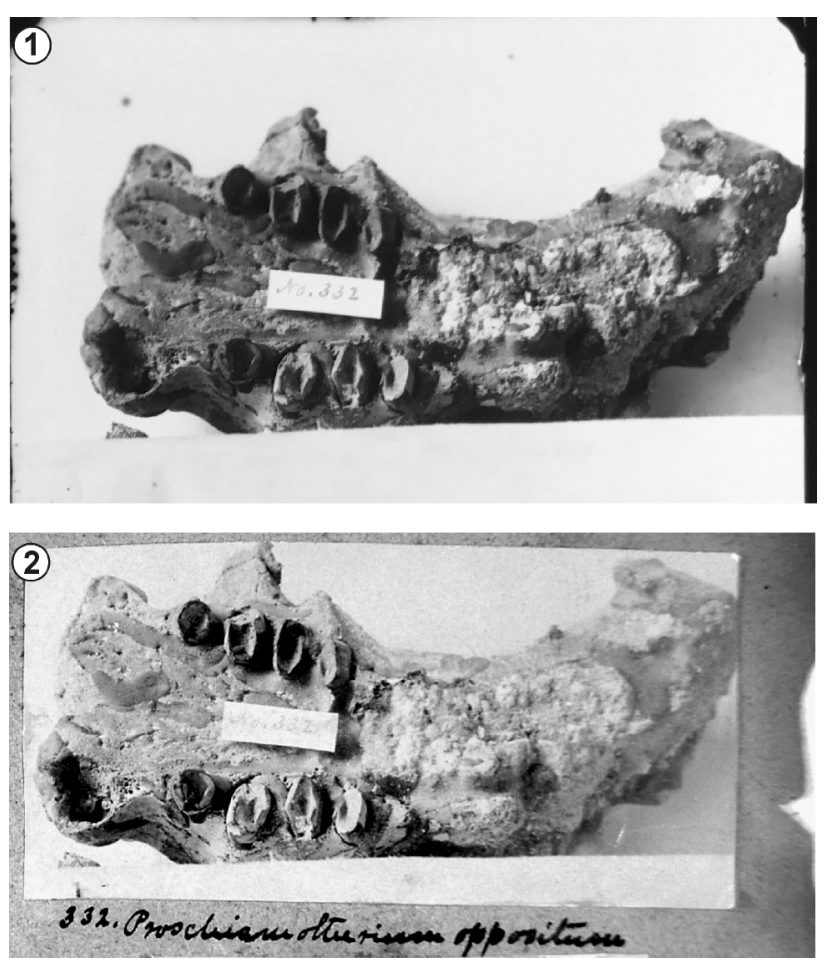

Figure 2. Images of the type specimen of the Santacrucian sloth Proschismotherium oppositum Ameghino, 1902 produced from: 1, Scott's glass plate negative; and 2, as it appears in the KUNHM album. The number "332" on the tag lying on the specimen is clearly visible. With permission of Leonard Krishtalka and the Biodiversity Institute, Division of Vertebrate Paleontology, University of Kansas for the images in the KUNHM album and to Christopher Norris and YPM VP for the contact print.

cover of Scott's notebook bears a stamp of the once very popular La Plata bookstore Papeleria de Jacobo Peuser (see Appendix 2, Supplementary Material) that was still in existence into the 1970s, thus indicating that Scott also purchased the notebook and almost certainly recorded the information on the images as he produced them while in Argentina. Finally, the handwritten captions to the photographs and notebook are a close match with other samples of Scott's handwriting, and not with Martin's (Fig. 3).

It is not clear how the album came to be in Kansas. Although Martin published no research on his Santa Cruz fossils, he did take the trouble to identify his specimens. Thus, his need for the album as an aid to fossil identification would have been during and immediately following his expedition (1903-ca. 1905). Of course, this was a time when Scott was presumably still using his own album for 

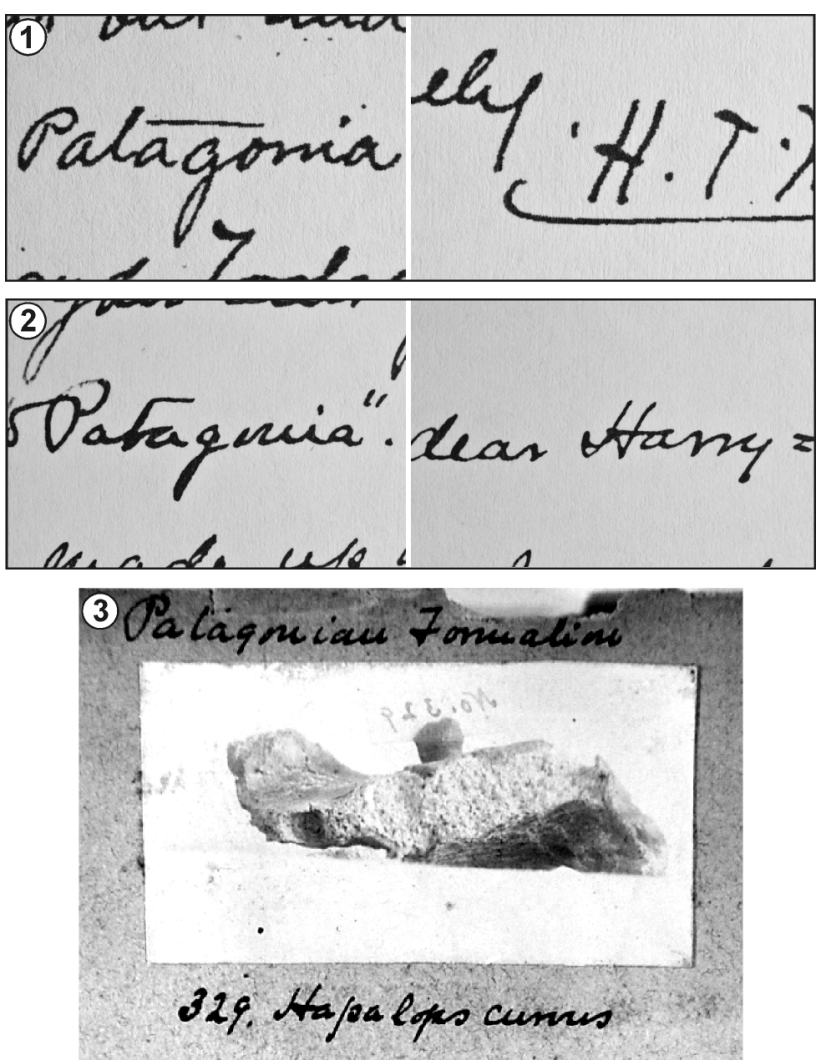

Figure 3. Handwriting samples of 1, H.T. Martin and 2, W.B. Scott compared with $\mathbf{3}$, an example of the handwritten entries in the KUNHM album. Note the close resemblance of the " $\mathrm{H}$ " and the words "Patagonia" and "Patagonian" in the Scott and KUNHM samples. The Martin sample is from a letter by H.T. Martin to the University of Kansas Chancellor, 30 December 1903, Handel T. Martin Collection, Kenneth Spencer Research Library, University of Kansas. The Scott sample is from a letter by W.B. Scott to H. F. Osborn, 16 February 1896, Field Correspondence, 1898-1900, Folder 9, Box 1, Patagonian Expedition, Department of Vertebrate Paleontology Archives, American Museum of Natural History. With permission of Leonard Krishtalka and the Biodiversity Institute, Division of Vertebrate Paleontology, University of Kansas for the images in the KUNHM.

comparative purposes while writing and editing the "Reports of the Princeton University Expeditions to Patagonia, 1896-1899". Indeed, Scott was still publishing drawings based on photographs from this album as late as 1928 , and therefore the album was probably still in his possession. By the time that Scott might have been willing to part with the album -once the Princeton reports were completedMartin no longer had any need for it.

A second possibility that we must consider is that Ameghino loaned or gave Martin his copy of Scott's album, and that Martin kept it, later giving it to or leaving it at the University of Kansas. In several ways, this explanation makes the most sense. Ameghino, after all, had no particular need for the album. At the same time, he would have recognized that Martin could make use of the album while in the field to help him identify fossils using Ameghino's taxa. This explanation, however, would seem to contradict Scott's claim that the albums he made were differently constituted (see above), as the album in Martin's possession appears to include images of more than just Ameghino's specimens. Possibly Scott misremembered or misrepresented the album he made for Ameghino. On the one hand, it would seem to have been easier to make two duplicate albums -especially if Scott already had the prints available. On the other hand, making prints using what Scott (1939, p. 250-251) called the "old-fashioned printing-out paper" process is evidently very time consuming and labor intensive.

A third possibility -arguably the most likely one- is that Scott's album was brought to the University of Kansas and incorporated into Martin's papers at a later date. Unfortunately, we have been unable to locate any information about how the album came to be at KUNHM. Searches for any such indication in Scott's correspondence in the Department of Rare Books and Special Collections, Princeton University Library, and Martin's sparse archived material in the Kenneth Spencer Research Library, University of Kansas, were negative.

\section{THE 1887 EXPEDITION, THE CONFLICT AND ITS CONSEQUENCES ON THE COLLECTION}

In July 1886, F. Ameghino became the "Secretario Subdirector" (or Assistant Director) of the then recently founded MLP and, soon after, C. Ameghino was hired as "Ayudante Preparador de Paleontología" (Assistant Preparator of Paleontology) and "Naturalista Viajero" (Travelling Naturalist) (see Fernicola, 2011a,b; Vizcaíno, 2011; Fernicola et al., 2014). C. Ameghino was sent by Moreno in February 1887 to the territory of Santa Cruz, in southernmost continental Patagonia, to collect fossils on the banks of the Río Santa Cruz. This would be the beginning of 16 years of field work by Carlos in Patagonia (Vizcaíno, 2011), but the only one conducted by him on behalf of the MLP. The remaining years 
were devoted to furthering the professional collaboration between the brothers. Indeed, the paleontological remains collected and the geologic sections and interpretations made by Carlos during his several trips served as the basis for the extensive geological and paleontological scientific reports of F. Ameghino (e.g., 1887, 1889, 1891, 1894, and 1906 , among others) that established the main elements, still considered essentially valid, of the sequence of South American Cenozoic time and faunas, based on the stratigraphic units and their interred fossil remains. Simpson (1948, 1984, p. 93) noted and reiterated that the brothers' "partnership was an outstanding example of teamwork, and their achievement was one of the most remarkable in scientific history."

During the 1887 expedition, C. Ameghino collected some 2000 fossil remains from four localities along the banks of the Río Santa Cruz from levels of the Santa Cruz Formation (lower Miocene). The fossil remains recovered from this formation are and have long been considered as the main basis for recognition of the Santacrucian South American Land Mammal Age (early Miocene). The initial descriptions of some of these remains were the subject of F. Ameghino's (1887) report that, albeit necessarily brief, included the description of 122 species, of which 110 were new (Fernicola et al., 2014), as noted above. Ameghino (1889) intended to and indeed did provide a more thorough account, as well as several illustrations, of this material, and erected a few other new Santacrucian taxa (the 1889 publication was on all Argentine fossil mammals until then known, rather than exclusively on the Santacrucian material), but he did not have access to all the specimens on which he had earlier established the new taxa, as explained below.

As mentioned above, F. Ameghino resigned from his MLP position in January 1888 and soon after was denied access to the collections (see Fernicola, 2011a,b). C. Ameghino's employment was terminated while he was in the field in the province of Chubut in March 1889. This complex situation, with F. Ameghino's intended fuller and more comprehensive account of the material now left potentially suspended, initiated several well-known problems that have plagued the 1887 collection and hindered recent attempts to revise the taxonomy and systematics of the Santacrucian taxa (see e.g., De luliis et al., 2014).

\section{THE IMPORTANCE OF THE ALBUM}

It may seem strange that a good many specimens from a few fossil collections from so restricted a geographical area became widely scattered, and that their identity has been and remains problematic. There are several reasons for this. One has been recorded above as due to F. Ameghino's break with Moreno and the former's subsequent dismissal from and denial of access to the MLP. Another factor has also been noted: the ambiguous records attached to specimens of the "Old collections" must have rendered the remains, at least a half century after they were collected, somewhat expendable and thus amenable to being exchanged, donated or sold. Yet another and perhaps overarching factor is that between 1887 and $1906 \mathrm{~F}$. Ameghino described a succession of fossil faunas very different from those known on other continents. He concluded that many of these species were geologically older than they are now known to be, and that they therefore constituted evidence of the presence in South America of the ancestors of many recent and modern mammalian clades, including that of humans. This was in marked contrast to the general opinion of the scientific authorities of the time that most (perhaps even all) mammalian groups had originated in the northern hemisphere, whence most of the fossil record had come. The combination of the quality of the fossils and the intellectual challenge of Ameghino's ideas aroused strong interest from other important academic centers of the world towards obtaining fossils from Santa Cruz for their own collections, research, and exhibitions. During the last decade of the nineteenth century and the first of the twentieth century, various institutions from abroad organized expeditions or hired independent collectors to obtain such collections (for a detailed account, see Vizcaíno et al., 2013). This heightened interest no doubt contributed to the desirability of specimens from Ameghino's private collection. As noted by several authors (e.g., Simpson, 1984), the sale of fossils was an important consideration for the Ameghino brothers; deprived of institutional support for their field and other research requirements, Florentino and Carlos had to depend on funds from family-run bookstores and the sale of fossils.

Although the question of the age of the South American fossil faunas was long ago resolved (Ameghino was incorrect 
in this regard), there remain many systematic and taxonomic issues, particularly with specimens described and taxa erected by F. Ameghino. Such issues have long been recognized, but efforts to resolve them have been hindered by the uncertainty over type specimens and on the identity of specimens reported (for example, by Scott, 1903, 1904) in the published literature; De luliis et al. (2014) provided a specific example. The problem becomes even more acute when the original type material has been mislaid and the album photographs remain the most important source of information pertaining to them. Thus, any record that helps establish the identity of such remains would be a valuable aid in resolving taxonomic and systematic issues.

The album of photographs is just such an aid. The collection of images allows a much better understanding than hitherto possible of which specimens were then in the MLP and which in Ameghino's private collection. It helps alleviate uncertainty over the identity of other specimens for example, it has already helped clarify which specimens Scott actually saw in the MLP and Ameghino's collection in connection with the sloth Schismotherium fractum Ameghino, 1887 (A. Racco pers. comm., 2017). Furthermore, visual records of the types, even though in several cases the specimens themselves no longer seem to be available, would be an invaluable aid to researchers attempting systematic and taxonomic research. Lastly, the images may prove useful in identifying Ameghino's (1887 and thereafter) specimens that made their way into other collections.

It is noted above that the album -practically beyond doubt- was Scott's work rather than Martin's. The images would be useful regardless, but we suggest that attribution of the album, with its nearly complete record of specimens (see explanatory notes for Appendix 1, Supplementary material), to Scott rather than to Martin increases confidence in the reliability of the identifications. Scott was an excellent vertebrate paleontologist, indeed one of the premier figures in this field during the late 1800 s and early 1900s, and academically motivated in research of the Santacrucian remains, whereas Martin, a collector and preparator, was chiefly motivated by personal rather than scientific concerns (Vizcaíno et al., 2016). Clearly, the identifications of the specimens were probably simply copied from information in the collections, but knowing that the specimens were those that Scott observed and published on would be of much greater value to researchers, rather than being those observed by Martin, who never published scientifically on Santa Cruz fossils.

Given the value of the photographs, it is useful to make the images readily available to other researchers. The images are reproduced digitally in their entirety here in Appendix 1 (Supplementary Material). Scott's notebook, which contains the "Index to Album, List of Negatives and Box List of the Photographs of Specimens in the Collections of La Plata \& Buenos Aires" is reproduced in Appendix 2 (Supplementary Material).

\section{CONCLUSIONS}

The album containing photographs of fossil specimens, the MLP, and Florentino Ameghino's house in La Plata that is currently, and apparently has for considerable time been, housed in the Division of Paleontology, University of Kansas, is most likely the original copy of W. B. Scott's photographic album. The latter photographed and assembled the album while in Argentina in 1901 during his research trip to examine fossil specimens from the Santa Cruz Formation in the possession of the MLP, MACN, and Florentino Ameghino. Given that we have been unable to uncover any correspondence between Martin and Scott, it is not known how the album came to be at KUNHM. The album contains an important record of the specimens present at the institutions noted and in possession of Florentino Ameghino near the turn of the last century, a period during which fossils from Santa Cruz aroused considerable scientific interest and were in very high demand among researchers and academic institutions. This record provides visual reference to these specimens and is highly useful in facilitating systematic and taxonomic research by helping to evaluate which specimens were used to erect the numerous taxa from the Santa Cruz and which were observed by other researchers that published on such remains. Given our desire to have this photographic resource material made available and used by other researchers, we have reproduced the images digitally in Appendix 1 (Supplementary Material). The original album has particular value as a historical and scientific document and securing its safekeeping is to be desired. While a good number of Scott's original glass nega- 
tives of the images and modern contact prints made from some of them are preserved in the YPM VP, many negatives are missing, so that the album is the only complete record of the images. Much pertinent information on the identity of the specimens is provided in Scott's notebook (Index to Album, List of Negatives and Box List of the Photographs of Specimens in the Collections of La Plata \& Buenos Aires). It is reproduced digitally here in Appendix 2 (Supplementary Material).

\section{ACKOWLEDGEMENTS}

This is a contribution to the projects ANPCYT PICT 2013-0389 and UNLP 11/N750 to SFV and NSF 1349741 to RFK. In 2013 SFV visited collections at Princeton University, Yale Peabody Museum and Kansas University, among other institutions thanks to a travel grant from the Universidad Nacional de La Plata (Argentina). We are grateful to Leonard Krishtalka and the Biodiversity Institute, Division of Vertebrate Paleontology, University of Kansas for permission to digitally reproduce all the images in the KUNHM album (Appendix 1, Suppl. Mat.), and to Christopher Norris and YPM VP for permission to digitally reproduce Scott's notebook (Appendix 2, Suppl. Mat.) and the contact print in Figure 2; the latter image was photographed by Jamie Henderson (YPM VP). We are grateful to the curators and collection managers of the KUNHM Linda Trueb, Desui Miao and David Burnham, who provided access to critical information about their collections and to Rebecca Schulte, University Archivist of the University of Kansas, and Brianna Cregle, Special Collections Assistant, Department of Rare Books and Special Collections, Princeton University Library. Cecilia M. Deschamps helped to assemble the digital album. The editor and two anonymous reviewers made useful suggestions on the original manuscript.

\section{REFERENCES}

Ameghino, F. 1887. Enumeración sistemática de las especies de mamíferos fósiles coleccionados por Cárlos Ameghino en los terrenos eocenos de la Patagonia. Museo de La Plata, Boletín 1: $1-26$.

Ameghino, F. 1889. Contribución al conocimiento de los mamíferos fósiles de la República Argentina. Academia Nacional de Ciencias de la República Argentina en Córdoba, Actas 6: 1-1028.

Ameghino, F. 1891. Nuevos restos de mamíferos fósiles descubiertos por Cárlos Ameghino en el Eoceno inferior de la Patagonia austral. Especies nuevas, adiciones y correcciones. Revista Argentina de Historia Natural 1: 289-328.

Ameghino, F. 1894. Enumération synoptique des espèces de mammifères fossiles des formations éocènes de Patagonie. Apartado de Boletín de la Academia Nacional de Ciencias en Córdoba 13: 259-452.

Ameghino, F. 1906. Les formations sédimentaries du Crétacé supérieur et du Tertiaire de Patagonie. Anales del Museo Natural de Buenos Aires 8: 1-358.

Bond, M. 1998. Santiago Roth. Museo (Revista de la Fundación Museo de La Plata) 13: 33-37.

Brinkman, P.D., and Vizcaíno, S.F. 2014. Clemente Onelli's sketch map and his first-hand, retrospective account of an early fossilhunting expedition along the Río Santa Cruz, southern Patago- nia, 1888-1889. Archives of Natural History 41: 326-337.

De luliis, G., Pujos, F., Toledo, N., Bargo, M.S., and Vizcaíno, S.F. 2014. Eucholoeops Ameghino, 1887 (Xenarthra, Tardigrada, Megalonychidae) from the Santa Cruz Formation, Argentine Patagonia: implications for the systematics of Santacrucian sloths. Geodiversitas 36: 209-255.

Farro, M.E. 2009. La formación del Museo de La Plata. Coleccionistas, comerciantes, estudiosos y naturalistas a fines del siglo XIX. Prohistoria Ediciones, Rosario, $234 \mathrm{p}$.

Fernicola, J.C. 2011a. Implicancias del conflicto Ameghino-Moreno sobre la colección de mamíferos fósiles realizada por Carlos Ameghino en su primera exploración al río Santa Cruz, Argentina. Revista Museo Argentino de Ciencias Naturales, n.s. 13: 41-57.

Fernicola, J.C. 2011b. 1886-1888: Ascenso, auge y caída de la sociedad entre Florentino Ameghino y Francisco P. Moreno. In: J.C. Fernicola, A. Prieto, and D. Lazo (Eds.), Vida y obra de Florentino Ameghino. Publicación Especial de la Asociación Paleontológica Argentina 12. Asociación Paleontológica Argentina, Buenos Aires, p. 35-49.

Fernicola, J.C., Cuitiño, J.I., Vizcaíno, S.F., Bargo, M.S., and Kay, R.F. 2014. Fossil localities of the Santa Cruz Formation (early Miocene, Patagonia, Argentina) prospected by Carlos Ameghino in 1887 revisited and the location of the Notohippidian. Journal of South American Earth Sciences 52: 94-107.

Kay, R.F., Perry, J.M.G., Malinzak, M.D., Allen, K.L., Kirk, E.C., Plavcan, J.M., and Fleagle, J.G. 2012. The paleobiology of Santacrucian primates. In: S.F. Vizcaíno, R.F. Kay, and M.S. Bargo (Eds.), Early Miocene Paleobiology in Patagonia: High-latitude Paleocommunities of the Santa Cruz Formation. Cambridge University Press, Cambridge, p. 306-330.

Lydekker, R. 1894. Contribuciones al conocimiento de los vertebrados fósiles de la Argentina. Parte 2. Anales del Museo de La Plata, Paleontología Argentina 1: 1-118.

Mercerat, A. 1891. Datos sobre restos de mamíferos pertenecientes a los Bruta conservados en el Museo de La Plata y procedentes de los terrenos Eocenos de Patagonia. Revista del Museo de La Plata 2: 5-46.

Rusconi, C. 1965. Carlos Ameghino. Revista del Museo de Historia Natural de Mendoza 17: 1-162.

Scott, W.B. 1903. Mammalia of the Santa Cruz beds. Part I. Edentata. In: W.B. Scott (Ed.), Reports of the Princeton University Expeditions to Patagonia 1896-1899. Princeton University Press, Princeton, p. 1-226.

Scott, W.B. 1904. Mammalia of the Santa Cruz beds. Part I. Edentata. In: W.B. Scott (Ed.), Reports of the Princeton University Expeditions to Patagonia 1896-1899. Princeton University Press, Princeton, p. 227-364.

Scott, W.B. 1939. Some Memories of a Palaeontologist. Princeton University Press, Princeton, $336 \mathrm{p}$.

Schuchert, C. 1897. What is a type in natural history? Science, New Series 5: 636-640.

Simpson, G.G. 1932. Some new or little-known mammals from the Colpodon beds of Patagonia. American Museum Novitates 575: $1-12$.

Simpson, G.G. 1948. The beginning of the age of mammals in South America. Part 1, Introduction: Systematics: Marsupialia, Edentata, Condylarthra, Litopterna and Notioprogonia. Bulletin of the American Museum of Natural History 91: 1-232.

Simpson, G.G. 1984. Discoverers of the Lost World. Yale University Press, New Haven, 222 p.

Vizcaíno, S.F. 2011. Cartas para Florentino desde la Patagonia. Cró- 
nica de la correspondencia édita entre los hermanos Ameghino (1887-1902). In: J.C. Fernicola, A. Prieto, and D. Lazo (Eds.). Vida y obra de Florentino Ameghino. Publicación Especial de la Asociación Paleontológica Argentina 12. Asociación Paleontológica Argentina, Buenos Aires, p. 51-67.

Vizcaíno, S.F., and Bargo, M.S. 2013. De Patagonia a Budapest: caminos europeos de fósiles santacrucenses (1845-1956). Museo (Revista de la Fundación Museo de La Plata) 26: 36-42.

Vizcaíno, S.F., Bargo, M.S., and Fernicola, J.C. 2013. Expediciones paleontológicas durante los Siglos XIX y XX a la Formación Santa Cruz (Mioceno Inferior, Patagonia) y destino de los fósiles. $3^{\circ}$ Congreso Argentino de Historia de la Geología (Salta), Actas: 231-246.

Vizcaíno, S.F., Brinkman, P.D., and Kay, R.F. 2016. On the objectives and results of the Handel T. Martin paleontological expedition (1903-04) to the Santa Cruz Formation in southern Patagonia. Revista del Museo de La Plata, Número Especial 1: 316-333.

Doi: 10.5710/PEAPA.21.06.2017.244

Recibido: 16 de mayo de 2017

Aceptado: 21 de junio de 2017 